Marquette University

e-Publications@Marquette

Mechanical Engineering Faculty Research and

Publications

Mechanical Engineering, Department of

$9-1-2017$

\title{
Communicating the Value of Ergonomics to Management - Part \\ 2: Ergonomics ROI Case Study Applications
}

Christopher R. Reid

The Boing Company

Peter W. Johnson

University of Washington

Richard W. Marklin Jr.

Marquette University, richard.marklin@marquette.edu

Patricia Seeley

Ergonomics Solutions

Peregrin Spielholz

The Boeing Company

See next page for additional authors

Follow this and additional works at: https://epublications.marquette.edu/mechengin_fac

\section{Recommended Citation}

Reid, Christopher R.; Johnson, Peter W.; Marklin, Richard W. Jr.; Seeley, Patricia; Spielholz, Peregrin; and Goggins, Rick, "Communicating the Value of Ergonomics to Management - Part 2: Ergonomics ROI Case Study Applications" (2017). Mechanical Engineering Faculty Research and Publications. 169.

https://epublications.marquette.edu/mechengin_fac/169 


\section{Authors}

Christopher R. Reid, Peter W. Johnson, Richard W. Marklin Jr., Patricia Seeley, Peregrin Spielholz, and Rick Goggins 


\title{
Communicating the Value of Ergonomics to Management - Part 2: Ergonomics ROI Case Study Applications
}

\section{Discussion Panel}

\author{
Christopher R. Reid ${ }^{1}$, Peter W. Johnson ${ }^{2}$, Richard W. Marklin, Jr. ${ }^{3}$, Patricia Seeley ${ }^{4}$, Peregrin Spielholz ${ }^{1}$, Rick \\ Goggins 5 \\ ${ }^{1}$ The Boeing Company, ${ }^{2}$ University of Washington, ${ }^{3}$ Marquette University, Milwaukee, WI \\ ${ }^{4}$ Consultant, Blaine, MN, ${ }^{5}$ Washington State Labor \& Industries
}

\begin{abstract}
More than ever, human factors engineers and ergonomists need to justify our practice's value to management. How can we effectively communicate with management? How should we present a Return on Investment (ROI) that leadership will find useful that addresses company profits, cost savings, productivity, first time quality, and turnover? What else does management care about other than ROI? This second panel in a two panel series will specifically highlight case studies in which presenters give examples of situations in which ROI for ergonomics was investigated from a business value. The session will start with four case study lectures followed by a panel discussion led by the moderators. The audience will be encouraged to participate with their own questions and comments.
\end{abstract}

\section{A COST-UTILITY ANALYSIS IN THE TRANSPORTATION SECTOR}

Peter W. Johnson, PhD

Dept. of Environmental and Occupational Health

Sciences, School of Public Health

University of Washington, Seattle, WA

Whole Body Vibration (WBV) is a risk factor for low back pain and accounts for a large proportion of claims costs in the transportation sector. As vehicle seats have a notable impact on WBV exposures, a predictive cost-utility analysis (CUA) was used to determine whether the installation and use of different bus driver seats in a regional bus municipality would affect bus driver compensation claim costs. Three seating alternatives were compared with the industry-standard practice of installing and using an air-suspension seat over the 15-year life of the bus: 1) installation of an active-suspension driver seat that would reduce WBV exposures up to $50 \%$; 2) installation of a static, suspension-less driver seat that would not alter WBV exposures but would reduce seat maintenance costs; and 3 ) replacement of the industry-standard bus driver seat every 5 years to reduce seat-related "wear-and-tear" increases in WBV exposures. Using 15 years of actual claims data from the bus municipality, the decisionanalytic Markov model of the CUA predicted the probability and the cumulative costs of bus drivers filing low back and/or neck claims. Over 15 years in the regional bus municipality's 1,500-bus fleet, the activesuspension seat was estimated to lower WBV exposures, reduce back-and neck-related claims, and save the bus municipality $\$ 4.8$ million dollars. A static, heightadjustable seats without a shock absorbing suspension did not alter WBV exposures, but was estimated to save \$2.0 million dollars over the same period through reduced seat maintenance costs; and finally, the purchase and periodic replacement of air-suspension seats every 5 years was estimated to increase costs by $\$ 2.4$ million dollars. These findings indicate that the adoption of active-suspension seats could improve bus driver health and also reduce the transit agency's claims costs. However, given the range of vehicle costs, claims costs, and vehicle service lives, caution may be merited with the generalizability of these findings to other segments in the transportation sector.

\section{PAYBACK PERIOD FOR BATTERY-POWERED TOOLS IN THE ELECTRIC POWER INDUSTRY} Richard W. Marklin, $\mathrm{Jr}^{1}$., PhD, CPE Patricia Seeley $^{2}$, MSIE, CPE

${ }^{1}$ Dept. of Mechanical Engineering Marquette University, Milwaukee, WI ${ }^{2}$ Blaine, $\mathrm{MN}$

Overhead and underground line work in the electric power industry is physically strenuous and cutting cable and crimping connectors with manual tools exposes workers to risk of musculoskeletal disorders (MSDs). In the 1990s battery-powered cable cutting and crimping tools were introduced to replace their manual counterparts, and only a small percentage of utilities 
used these tools. EPRI (Electric Power Research Institute) sponsored a biomechanical study to quantify the musculoskeletal benefits of the battery-powered tools. This laboratory study found that the batterypowered tools reduced the muscular force of the trunk and upper extremity muscles substantially and reduced the risk of MSDs (Marklin and Yager, 2001).

In 2002 an ROI analysis was performed to determine whether the cost of the battery-powered tools, which typically cost more than $\$ 2000$, was justified to replace the manual tools, which cost approximately $\$ 300$, for utility line workers. Data from a major medium-sized utility were analyzed and took into account the following factors:

- Review of injuries over a 5-year period

- Workers' compensation and medical costs of injuries

- Cost of replacement workers and their training

- Cost of new tools

- Cost of repair and replacement of tools and batteries

- Productivity enhancements with new tools

The ROI analysis found that the payback period for a battery-powered tool was 14 months if the tool was purchased outright and 3 months if the tool's cost was capitalized over 5 years (Seeley and Marklin, 2008; Seeley et al., 2008). Based on payback period results, a major medium-sized electric utility purchased \$2 million worth of battery tools in the early 2000s, and this utility continued to purchase more tools to outfit every line crew in the company, resulting in a total expenditure of approximately $\$ 5$ million. Other electric utilities have followed a similar approach, and the result is that battery-powered cutting and crimping tools are now standard for most US and Canadian electric utilities.

\section{APPLICATIONS OF COST-BENEFIT ANALYSIS IN PRODUCTION AND PRODUCT DESIGN DECISION-MAKING \\ Peregrin Spielholz, $\mathrm{PhD}$ \\ The Boeing Company, Seattle, WA}

Are there instances where it is in the company's interest to invest in an improvement when there is a negative business case from the cost accounting model? If so, what are the conditions and assumptions applied that sometimes turn a seemingly negative case to a positive one? Many indirect costs cannot be directly determined on the company's income statement, like insurance premiums and direct medical reimbursements. Some examples of indirect costs include: Damage to equipment, machinery, materials, and facility;
Production downtime; Lower employee morale and engagement; Loss of products or services; Potential liability and legal actions; Delays in shipment or filling orders. A number of studies have looked to quantify the ratio between direct and indirect workplace injury costs. The overall story appears to be that the Direct:Indirect cost ratio depends on several factors but that the ratio, on average, is somewhere between 1:1 on the low-end, and 1:4.5 on the high-end. Application of a company costbenefit model to assess injury cost impacts on proposed and approved production and product design projects. A discussion of alternative presentations of impacts and data will be reviewed to help expand analysis beyond cost avoidance.

\section{PREDICTIVE COST-BENEFIT ANALYSIS IN HEALTH CARE \\ Rick Goggins, CPE \\ Division of Occupational Safety \& Health Washington State Labor \& Industries, Olympia, WA}

There is a clear benefit to being able to demonstrate that the work that we do has economic value. While case studies on the benefits of ergonomics are easy to find, there is a lack of high-quality studies that include thorough economic analyses. One possible reason for the lack of high-quality evidence is the inherent difficulty in gathering cost-benefit data. While the costs to implement a program or piece of equipment are often easy to identify, the value of benefits may not be readily apparent, and may be difficult to monetize even after successful implementation. It can be even more challenging to develop a compelling business case for an ergonomics intervention prior to implementation. But practitioners are often faced with a need to convince decision-makers of the value of a project in order to get funding for it. One possible approach would be to develop a predictive cost-benefit model based on published results of similar projects. In healthcare, there are numerous examples of cost-benefit analyses for safe patient handling and mobility (SPHM) programs that can be used to construct a predictive model. The model could then be validated through post-implementation cost-benefit analysis.

\section{REFERENCES}

Marklin, R.W. and Yager, J. (2001). EPRI Ergonomics Handbook for the Electric Power Industry: Overhead Distribution Line Workers Interventions. EPRI, Palo Alto CA, document \#1005199. 
Seeley, P. and Marklin, R.W. (2003). Cost justification of battery-operated tools for overhead line workers in the electric power industry. Applied Ergonomics, 34(5), 429439.

Seeley, P., Marklin, R., Usher, D. and Yager, J. (2008). Case study report: Business case for implementing batterypowered tools for direct-bury line workers at an electric power utility. Journal of Occupational and

Environmental Hygiene, 5:D86-D91. 